\title{
STUDI KOMUNITAS NEKTON DI KAWASAN KONSERVASI KURA-KURA UNIVERSITAS BENGKULU DAN PENGEMBANGAN PEMBELAJARAN BERBASIS LINGKUNGAN
}

\author{
(Study of Nekton Community in Turtle Conservation Area \\ University Bengkulu and Development \\ Environment-Based Learning)
}

\author{
Desi Enersy ${ }^{1 *}$, Bhakti Karyadi ${ }^{2}$, Endang Widi Winarni ${ }^{2}$ \\ ${ }^{1}$ Mahasiswa Program Pascasarjana S2 Pendidikan IPA Universitas Bengkulu \\ ${ }^{2}$ Dosen Program Pascasarjana S2 Pendidikan IPA Universitas Bengkulu \\ *Email: desienersy@yahoo.co.id
}

\begin{abstract}
This study aims to inventory the type of necton, knowing the structure of the necton community and measuring the critical thinking skills of students of class VII.1 SMPN 1 Ujan Mas Kepahiang. The results showed that the necton obtained from the Taman Pintar pond amounted to 7 species and Pipi Putih Pond totaling 4 species. The necton species in the Taman Pintar pond with the highest KP, KS, and FK values are tin head fish with KP, $\mathrm{KR}$, and FK values respectively $0.102 \mathrm{idv} / \mathrm{m} 2,75.71 \%$ and $83 \%$. While on the Pipi Putih Pond is local catfish species with the value of KP, KR, FK of $0.01 \mathrm{idv} / \mathrm{m} 2,39.29 \%$ and $25 \%$. Then dominance index $\left(\mathrm{H}^{\prime}\right)$ in the Taman Pintar pond is 0.61 and $\mathrm{C}^{\prime}$ Pipi Putih pond $=0.76$. While the index of diversity of necton species in both ponds also belonged to very low category with $\mathrm{H}^{\prime}$ value of Taman Pintar Pond $=0.28$ and $\mathrm{H}^{\prime}$ of Pipi Putih pond $=0.17$. The result of Percentage Of Agreement test showed that environment-based learning tools developed are included in the category highly feasible to be tested. Students' critical thinking ability on the perpormance aspect shows $33,3 \%$ percentage including critically critical criteria and $66,7 \%$ including critical criteria. While Students' critical thinking ability on the cognitive aspect shows four criteria, that are very critical as $26 \%$, crittical criteria $40 \%$, criteria critical enough $27 \%$ and criteria less $7 \%$
\end{abstract}

Keywords: Nekton, environment-based learning, critical thinking ability

\section{ABSTRAK}

Penelitian ini bertujuan untuk menginventarisasi jenis nekton,mengetahui struktur komunitas nekton dan mengukur kemampuan berpikir kritis siswa kelas VII.1 SMPN 1 Ujan Mas Kepahiang. Hasil penelitian menunjukkan bahwa nekton yang diperoleh dari Kolam Taman Pintar berjumlah 7 Spesies dan kolam Pipi Putih berjumlah 4 Spesies. Spesies nekton pada Kolam Pintar yang memiliki nilai KP,KS, dan FK paling tinggi adalah Ikan kepala timah dengan nilai KP,KR, dan FK secara berturut turut yaiu $0,102 \mathrm{idv} / \mathrm{m}^{2}$, $75,71 \%$ dan $83 \%$. Sedangkan pada Kolam Kura-Kura Pipi Putih adalah spesies lele lokal dengan nilai $\mathrm{KP}, \mathrm{KR}$, FK sebesar $0,01 \mathrm{idv} / \mathrm{m}^{2}, 39,29 \%$ dan $25 \%$. Indeks dominansi (H') di Kolam Pintar adalah 0,61 dan C' Kolam kura-Kura Pipi Putih $=0,76$. Sedangkan indeks keanekaragaman spesies nekton pada kedua kolam juga termasuk kategori sangat rendah dengan nilai H' Kolam Taman Pintar $=0,28$ dan H' Kolam Pipi Putih=0,17. Hasil uji Percentage Of Agreement menunjukan bahwa perangkat pembelajaran berbasis lingkungan yang dikembangkan termasuk dalam kategori sangat layak untuk diuji cobakan. Kemampuan berpikir kriitis siswa pada aspek kinerja menunjukkan persentase $33,3 \%$ dalam kriteria sangat kritis dan 66,7 \% termasuk dalam kriteria kritis, sedangkan kemampuan berpikir kritis siswa pada aspek kognitif menunjukkan empat kriteria yaitu kriteria sangat kritis sebanyak $26 \%$, kriteria kritis sebanyak $40 \%$, kriteria cukup kritis sebanyak $27 \%$ dan kriteria kurang kritis sebanyak $7 \%$. 


\section{Kata Kunci: Nekton, pembelajaran berbasis lingkungan, kemampuan berpikir kritis \\ PENDAHULUAN}

Keanekaragam hayati yang berlimpah pada setiap ekosistem tentu saja dapat dimanfaatkan untuk memenuhi kebutuhan hidup masyarakat yang berada di wilayah berbagai eksosistem. Akan tetapi dengan penggunaan sumber daya hayati yang melebihi batas, maka tidak akan menutup kemungkinan bahwa pada suatu saat nanti keanekaragaman hayati yang ada di ekosistem wilayah provinsi Bengkulu juga akan mengalami suatu permasalahan yang besar yaitu mengalami tingkat kepunahan. Oleh karena itu sudah selayaknya masyarakat sebagai warga yang sangat berhubungan dengan keanekaragaman hayati tersebut dapat memikirkan bagaimana cara untuk menyelamatkan kenaekaragaman hayati tersebut. Salah satu caranya adalah dengan melakukan suatu kegiatan yang bersifat konservasi. Taman pintar dan Taman Pipi Putih Universitas Bengkulu merupakan salah satu contoh kenekaragaman ekosistem kolam yang dimanfaatkan sebagai wilayah konservasi. Pada Kolam pintar terdapat dua jenis Kurakura yang di konservasi yaitu kura-kura garis hitam (Cyclemys oldhamii). Sedangkan kolam Pipi putih dijadikan area konservasi kurakura pipih putih (Siebenrockiella crassicollis). Berdasarkan hasil penelitian Sinaga (2016) yang menyatakan bahwa laju konsumsi paling tinggi kura-kura jenis Cyclemys oldhamii adalah pada pemberian pakan 100 $\%$ ikan nila (jenis daging) dari pada tumbuhan, serta hasil penelitian Ningsih (2016) bahwa laju pertumbuhan tertinggi S.crassicollis adalah juga pada pemberian pakan $100 \%$ ikan nila, maka sebagai upaya untuk mendukung kegiatan konservasi kedua jenis kura-kura tersebut, perlu dilakukan penelitian tentang Studi Komunitas Nekton di Kawasan Konservasi Taman Pintar dan Kolam Kura-Kura Pipi Putih. Sedangkan

\section{METODE}

Penelitian ini terdiri dari 2 tahap yaitu penelitian tentang studi komunitas nekton dan dilanjutkan dengan penelitian pengembangan pembelajaran berbasis lingkungan yang dilaksanakan. Penelitian studi komunitas nekton penelitian ini untuk faktor abiotik (faktor lingkungan yang sberupa faktor kedalaman, kekeruhan, suhu, $\mathrm{pH}, \mathrm{BOD}, \mathrm{COD}$ ). Pembelajaran IPA (Sains) merupakan ilmu yang mempelajari fenomena-fenomena di alam semesta, yang juga memperoleh kebenaran tentang fakta dan fenomena alam melalui kegiatan empirik yang dapat diperoleh melalui eksperimen laboratorium atau alam bebas. Dengan demikian merencanakan pembelajaran IPA yang mengembangkan berpikir kritis merupakan suatu keharusan dalam upaya mencapai tujuan pendidikan. Dengan konsep belajar berpikir kritis maka siswa akan memperlihatkan pikiran-pikiran dan proses diantaranya: (1)Mengajukan pertanyaan seperti "Bagaimana kita tahu"? atau "Apa buktinya"?; (2)Mengalami perbedaan antara observasi dengan kesimpulan;

Mengetahui bahwa diperlukan bukti yang cukup untuk menarik kesimpulandan; (4) Memberi penjelasan atau interpretasi, observasi, dan prediksi (Winarni, 2012).Pembelajaran berbasis lingkungan merupakan salah satu upaya terciptanya pembelajaran yang menyenangkan, terhindar dari kejenuhan, kebosanan, dan persepsi belajar hanya dalam kelas. Melalui pengembangan pembelajaran berbasis lingkungan, maka siswa akan diajak untuk berinteraksi langsung dengan sumber belajar dalam hal ini lingkungan, sehingga pada saat kegiatan pembelajaran siswa akan langsung mengamati, bekerja serta menyimpulkan dari hasil kegiatan pembelajaran yang sudah dilalui tersebut serta sehingga pada akhirnya dapat melatih siswa untuk berpikir kritis. Dengan demikian perlu dilakukan penelitian tentang pengembangan pembelajaran berbasis lingkungan yang akan digunakan untuk mengukur kemampuan berpikir kritis siswa.

dilaksanakan pada bulan Januari sampai Maret 2017, Penangkapan nekton dengan menggunakan metode purposive sampling. langkah penelitian dimulai dengan membagi kolam menjadi 12 plot. Kemudian setiap plot diletakkan alat tangkap Nekton (bubu dan jala). Alat tangkap diletakkan selama 6 
sampai 12 Jam. Nekton yang diperoleh selanjutnya dilakukan inventarisai dan di analisa dengan menggunakan rumus kepadatan populasi, kelimpahan relatif, frekwensi kehadiran, indeks dominansi, dan indeks keanekaragaman (Latupapua,2011 dan Juanedi,2014).

\section{Penelitian pengembangan pembelajaran berbasis lingkungan}

Penelitian ini dilakukan dengan model pengembangan research and development dengan menggunakan uji coba skala kecil (Dick and Carey) pada kelas VII.1 SMPN 1 Ujan Mas Kepahiang. Penelitian dilakukan dengan langkah-langkah Dick and Carey yang meliputi

a. Tahap 1 (Merancang / perencanaan serta pengembangan kegiatan pembelajaran.

Pada tahapan ini akan dilakukan beberapa kegiatan diantaranya meliputi Menentukan Tujuan Pembelajaran, Melakukan Analisis pembelajaran, Mengembangkan

Penilaian,pengembangan

Pembelajaran, dan

Perangkat Pembelajaran

b. Tahap 2 ( validasi ).

Pada tahap 2 ini akan dilakukan kegiatan validasi terhadap perangkat pembelajaran yang sudah dikembangkan. Kegiatan Validasi ahli (expert judgement) dilakukan oleh guru senior dan dosen. Adapun perangkat pembelajaran yang akan divalidasi adalah Silabus, RPP, LKPD serta instrumen penilaian kinerja siswa.

c. Tahap 3 (revisi).

Pada tahap ini akan dilakukan revisi atau perbaikan terhadap perangkat pembelajaran yang sudah di validasi oleh ahli.

\section{d. Tahap 4. Uji coba skala kecil (uji formatif)}

Perangkat pembelajaran yang sudah di revisi pada tahap tiga di atas selanjutnya dilakukan uji coba dalam skala kecil (uji formatif). Uji coba pembelajaran dilakukan di kelas VII.1 SMPN 1 Ujan Mas yang berjumlah
15 orang. Pengambilan skala uji coba sebanyak 15 siswa, Ini sesuai dengan model pengembangan Dick dan Carey bahwa untuk uji coba skala kecil jumlah yang diperlukan hanya delapan sampai dua puluh siswa. Kegiatan Uji Coba ini bertujuan untuk mengukur Kemampuan Berpikir Kritis dari aspek kinerja dan dari aspek kognitif dengan menggunakan dimensi dan indikator menurut Ennis (2011) dalam Winarni (2012).

\section{HASIL DAN PEMBAHASAN}

\section{Penelitian studi komunitas nekton}

Hasil penelitian menunjukkan bahwa pada ekosistem kolam taman pintar diperoleh 7 spesies nekton, sedangkan pada ekosistem kolam pipih putih diperoleht 4 spesies nekton. Tujuh spesies nekton yang terdapat di ekosistem kolam pintar tersebut adalah Oreochromis niloticus (ikan nila), Trichogaster trichopterus (ikan sepat), Channa striata (ikan gabus), Monopterus albus (belut), Anguilla marmorata (sidat/ pelus), Aplocheilus panchax (ikan kepala timah), dan Litopenaeus vannamei (Udang putih). Sedangkan 4 spesies nekton yang diperoleh dari ekosistem kolam pipih putih adalah Oreochromis niloticus (ikan nila), Trichogaster trichopterus (ikan sepat), Monopterus albus (belut), dan Clarias batracus (lele lokal).

Tabel 1. Nilai kepadatan populasi (KP), kelimpahan relatif $(\mathrm{KR})$ dan Frekwensi kehadiran (FK)

\begin{tabular}{|c|c|c|c|c|c|c|}
\hline \multirow[t]{3}{*}{ Jenis Nekton } & \multicolumn{6}{|c|}{ Ekosistem } \\
\hline & \multicolumn{3}{|c|}{$\begin{array}{c}\text { Kolam } \\
\text { Taman Pintar }\end{array}$} & \multicolumn{3}{|c|}{$\begin{array}{c}\text { Kolam Pipi } \\
\text { Putih }\end{array}$} \\
\hline & $\mathrm{KP}$ & $\mathrm{KR}$ & $\begin{array}{l}\mathrm{F} \\
\mathrm{K}\end{array}$ & $\mathrm{KP}$ & $\begin{array}{l}\mathrm{K} \\
\mathrm{R}\end{array}$ & FK \\
\hline $\begin{array}{l}\text { 1. Nila } \\
\text { (Oreochromis } \\
\text { niloticus) }\end{array}$ & $\begin{array}{l}0,0 \\
01\end{array}$ & 0,5 & 4 & $\begin{array}{l}0,0 \\
01\end{array}$ & $\begin{array}{l}9, \\
8 \\
2\end{array}$ & 4 \\
\hline $\begin{array}{l}\text { 2. Ikan sepat } \\
\text { (Trichogaster } \\
\text { trichopterus) }\end{array}$ & $\begin{array}{c}0,0 \\
2\end{array}$ & $\begin{array}{l}18, \\
51\end{array}$ & $\begin{array}{l}7 \\
3\end{array}$ & $\begin{array}{l}0,0 \\
02\end{array}$ & $\begin{array}{l}2 \\
5, \\
9\end{array}$ & 17 \\
\hline $\begin{array}{l}\text { 3. Gabus } \\
\text { (Channa } \\
\text { striata) }\end{array}$ & $\begin{array}{l}0,0 \\
02\end{array}$ & $\begin{array}{c}1,4 \\
6\end{array}$ & 6 & - & - & - \\
\hline $\begin{array}{l}\text { 4. Belut } \\
\text { (Monopterus }\end{array}$ & $\begin{array}{l}0,0 \\
02\end{array}$ & $\begin{array}{c}1,1 \\
2\end{array}$ & $\begin{array}{l}1 \\
0\end{array}$ & $\begin{array}{l}0,0 \\
01\end{array}$ & $\begin{array}{l}2 \\
5\end{array}$ & 8 \\
\hline
\end{tabular}




\begin{tabular}{|c|c|c|c|c|c|c|}
\hline albus) & & & & & & \\
\hline $\begin{array}{l}\text { 5. Pelus } \\
\text { (Anguilla } \\
\text { marmorata) }\end{array}$ & $\begin{array}{c}0,0 \\
01\end{array}$ & $\begin{array}{c}0,6 \\
3\end{array}$ & 6 & - & - & - \\
\hline $\begin{array}{l}\text { 6. Kepala } \\
\text { timah } \\
\text { (Aplocheilus } \\
\text { panchax) }\end{array}$ & $\begin{array}{l}0,1 \\
02\end{array}$ & $\begin{array}{l}75, \\
71\end{array}$ & $\begin{array}{l}8 \\
3\end{array}$ & - & - & - \\
\hline $\begin{array}{l}\text { 7. Udang putih } \\
\text { (Fenneropena } \\
\text { indicus) }\end{array}$ & $\begin{array}{l}0,0 \\
03\end{array}$ & $\begin{array}{c}2,0 \\
9\end{array}$ & 6 & - & - & - \\
\hline $\begin{array}{l}\text { 8. Lele lokal } \\
\text { (Clarias } \\
\text { patracus) }\end{array}$ & - & - & - & $\begin{array}{l}0,0 \\
10\end{array}$ & $\begin{array}{l}3 \\
9, \\
3\end{array}$ & 25 \\
\hline
\end{tabular}

ket: KP: kepadatan populasi, KR: kelimpahan relatif, dan FK: frekwensi kehadiran

Dari Tabel 1 di atas, dapat dinyatakan bahwa hasil penelitian menunjukkan pada ekosistem kolam pintar, spesies ikan yang mempunyai nilai kepadatan populasi, kelimpahan spesies dan frekwensi kehadiran paling tinggi adalah spesies ikan kepala timah. Dari hasil penelitian yang dilakukan sebanyak 4 kali pengulangan, didapatkan rata-rata nilai kepadatan populasi (KP) sebesar 0,102 idv/ $/ \mathrm{m}^{2}$, KR (Kelimpahan Relatif) sebesar 75,71\% serta Frekwensi Kehadiran (FR) sebesar $83 \%$ (kategori sangat banyak).Sedangkan spesies yang yang memiliki tingkatan Kepadatan Populasi, Kelimpahan Relatif dan Frekwensi paling rendah adalah spesies ikan nila. Ini ditunjukkan dengan nilai KP sebesar 0,001 $\mathrm{idv} / \mathrm{m}^{2}$, nilai $\mathrm{KR}$ sebesar $0,50 \%$. Sedangkan nilai FK adalah $4 \%$ (sangat jarang).

Pada ekosistem Kolam Pipi Putih, dapat dikemukakan bahwa spesies yang mempunyai tingkat kepadatan populasi, kelimpahan relatif dan frekwensi kehadiran paling tinggi adalah spesies ikan lele lokal. Spesies ini memiliki nilai KP, KR, dan FK yang lebih tinggi jika dibandingkan dengan 3 spesies yang lainnya. Spesies lele memiliki nilai kepadatan populasi sebesar 0,010 $\mathrm{idv} / \mathrm{m}^{2}$, kelimpahan relatif sebesar $39,29 \%$, serta frekwensi kehadiran sebesar $25 \%$ (jarang). Untuk spesies yang memiliki nilai kepadatan populasi, kelimpahan spesies dan frekwensi kehadiran paling rendah adalah spesies ikan nila ( Oreochromis niloticus) yaitu dengan nilai KP sebesar $0,001 \mathrm{idv} / \mathrm{m}^{2}$, nilai KR sebesar 9,82 \% dan FK sebesar $4 \%$ (sangat rendah).

Tingginya nilai kepadatan populasi ikan kepala timah jika dibandingkan dengan kepadatan populasi spesies ikan yang lainnya, kemungkinan disebabkan karena faktor ketersediaan pakan pada kolam tersebut. Ikan kepala timah merupakan jenis ikan yang memakan jentik nyamuk (Riana, 2015). Seperti diketahui di kolam pintar banyak sekali terdapat jentik nyamuk. Selain itu pada ekosistem kolam pintar tersebut sebagian besar wilayahnya terdapat banyak rumput yang juga merupakan makanan dari jenis ikan tersebut. Ikan nila(Oreochromis niloticus) merupakan spesies nekton yang memilikinilai kepadatan populasi paling rendahKP sebesar $0,001 \mathrm{idv} / \mathrm{m}^{2}$. Rendahnya nilai kepadatan populasi ikan nila(Oreochromis niloticus)pada ekosistem kolam pintar dan ekosistem kolam pipi putih diduga disebabkan karena kalahnya spesies ikan nila berkompetisi dalam hal mendapatkan makanan. Menurut Rukmana (1997) dalam Siagian (2009) jenis makanan yang paling disukai oleh ikan nila(Oreochromis niloticus) adalah Fitoplankton (tumbuhan air dan organisme renik yang melayang) dan tumbuhan air. Perbedaan nilai kepadatan populasi spesies nekton yang berada di kawasan konservasi kura-kura ini tidak terlepas dari beberapa faktor yang mempengaruhi. Menurut Iskandar, 2013 " Faktor yang menyebabkan meningkatnya kepadatan popualsi diantaranya: natalitas (kelahiran), perpindahan kedalam (imigrasi) serta penyempitan wilayah. Sedangkan faktor yang menyebabkan menurunnya kepadatan populasi diantaranya adalah kematian (mortalitas), perpindahan keluar (emigrasi), serta perluasan wilayah.

\section{Nilai indeks dominansi (C') dan indeks keanekaragaman (H')}

Indeks dominansi merupakan nilai yang menyatakan tingkat dominansi suatu spesies yang ada pada suatu ekosistem, sedangkan indeks keanekaragaman sharoon winner merupakan suatu nilai yang menyatakan tingkat keanekaragaman 
spesies yang ada pada suatu ekosistem. Dari hasil penghitungan, diperoleh nilai indeks dominansi (C') dan indeks keanekaragaman $\left(\mathrm{H}^{\prime}\right)$ seperti pada Gambar 1.

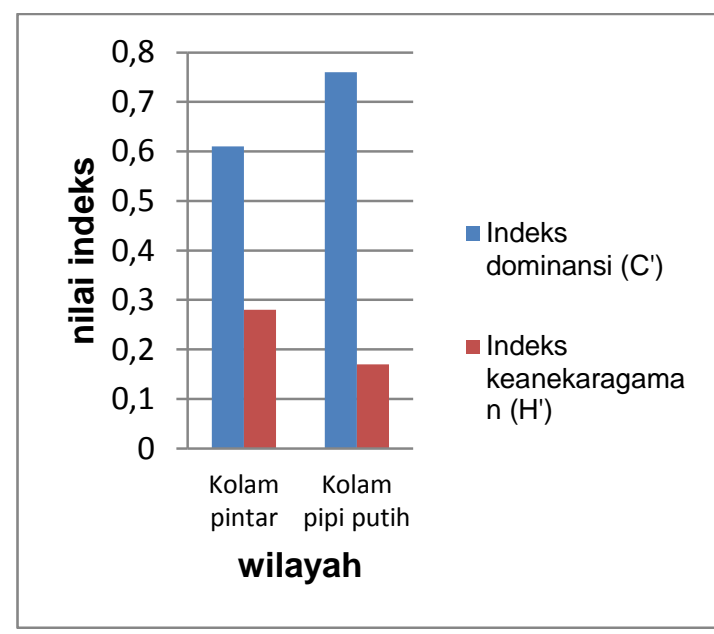

Gambar 1. Grafik nilai Indeks

dominansi (C') dan Indeks keanekaragaman $\left(\mathrm{H}^{\prime}\right)$

Gambar 1 menunjukkan hasil nilai indeks dominansi dan nilai indeks keanekaragaman nekton pada kedua wilayah ekosistem (baik ekosistem kolam pintar maupun ekosistem kolam pipi putih). Adapun nilai untuk indeks dominansi nekton dari kedua kolam tersebut yaitu pada kolam pintar nilai indeks dominansi ( (C') sebesar 0,61. Sedangkan pada kolam pipi putih nilai indeks dominansi (C') hanya sebesar 0,76 . Selain nilai indeks dominansi nekton, gambar 1 juga menunjukkan nilai indeks keanekaragaman nekton pada kedua wilayah kolam. Adapun hasilnya adalah indeks keanekaragaman $\left(\mathrm{H}^{\prime}\right)$ pada kolam pintar sebesar 0,28 dan nilai indeks kenekaragaman $\left(\mathrm{H}^{\prime}\right)$ pada kolam pipi putih sebesar 0,17. Dari haasil dapat disimpulkan bahwa pada kedua kolam tidak ada spsies yang mendominasi. Hal ini ditunjukkan dari nilai indeks dominansi spesies kolam pintar 0,61 dan indeks dominansi di kolam pipi putih 0,76. Menurut Junaidi, dkk.2014" Jika nilai indeks $=1$ menunjukkan dominansi oleh satu spesies sangat tinggi, sedangkan jika nilai indeks $=0$ menunjukkan bahwa diantara jenis-jenis yang ditemukan tidak ada yang dominansi.

Berdasarkan analisis hasil penelitian, juga dapat dinyatakan bahwa keanekaragaman spesies yang ada pada kedua ekosistem (kolam pintar dan kolam pipi putih) adalah rendah. Ini dapat dilihat dari nilai indks kenaekaragaman( $\left.\mathrm{H}^{\prime}\right)$ yang diperoleh di kolam pintar yang hanya 0,28 sedangkan di kolam pipi putih hanya 0,17. Hal ini sesuai dengan pendapat Fachrul, 2007 dan Latupapua, 2011 yang menyatakan bahwa nilai $\mathrm{H}^{\prime}>3,0$ menunjukan tingkat keanekaragaman yang sangat tinggi. $H$ ' $>1,5-3,0$ menunjukan tingkat keanekaragaman yang tinggi. $H^{\prime}>1,0-1,5$ menunjukan tingkat keanekaragaman sedang. $\mathrm{H}^{\prime}<1$ menunjukan tingkat keanekaragaman rendah.

\section{Penelitian pengembangan pembelajaran berbasis lingkungan.}

Hasil validasi perangkat pembelajaran

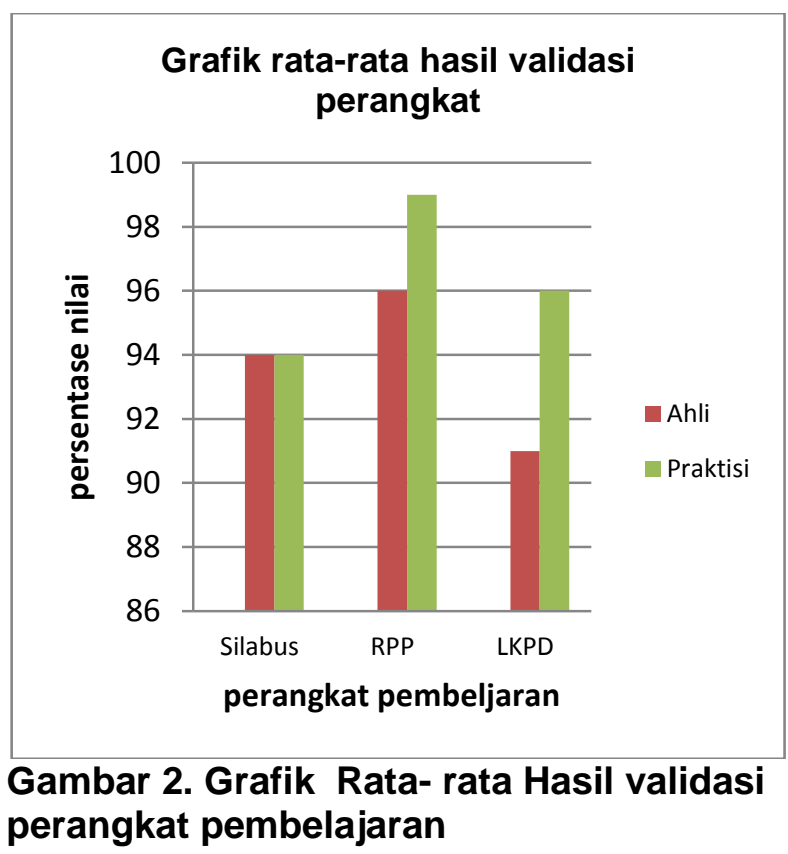

Gambar 2 menunjukkan persentase nilai Validasi Perangkat Pembelajaran berbasis lingkungan dari semua Validator. Untuk perangkat silabus diperoleh nilai ratarata yang sama dari validator ahli dan praktisi yaitu sebesar $94 \%$. Pada perangkat RPP nilai dari Validator Ahli $96 \%$, sedangkan Validator Praktisi sebesar $99 \%$. Sedangkan untuk perangkat LKPD, nilai rata-ratadari Validator Ahli sebesar $91 \%$ dan nilai dari Validator Praktisi sebesar 96 \%. Dari hasil Persentase nilai rata-rata yang diperoleh, 
maka perangkat silabus termasuk ke dalam kriteria sangat baik/ sangat layak digunakan. Menurut Amarila dkk,(2014) instrumen harus mendapat nilai > 63 untuk dapat digunakan

\section{Hasil pengukuran kemampuan berpikir} kritis dari aspek kinerja

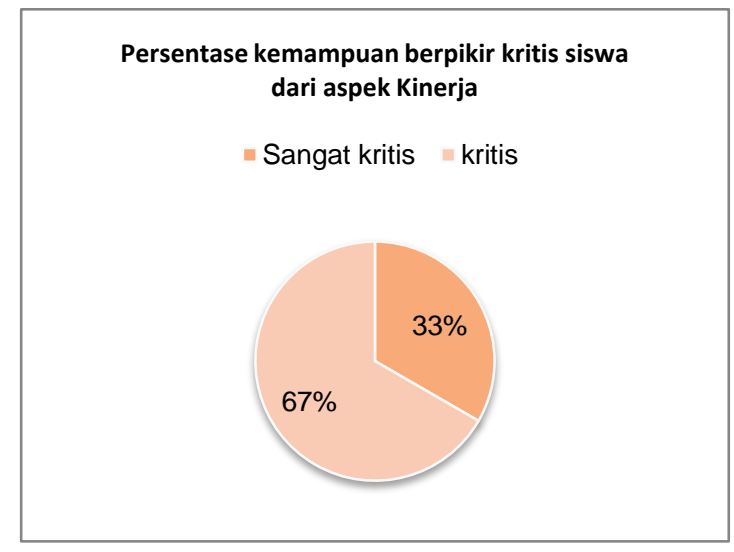

Gambar 3 di atas menyatakan persentase kemampuan berpikir kritis siswa dari aspek kinerja pada KD 4.7 menyajikan hasil pengamatan terhadap interaksi makhluk hidup dengan lingkungan sekitarnya. Hasil penelitian menunjukkkan bahwa rata-rata kemampuan berpikir kritis dari aspek kinerja yang paling tinggi berada pada kriteria kritis. Hal ini ditunjukkan dengan persentase yang mencapai $67 \%$. Sedangkan yang termasuk kedalam kriteria sangat kritis mencapai $33 \%$

Hasil pengukuran kemampuan berpikir kritis dari aspek kognitif

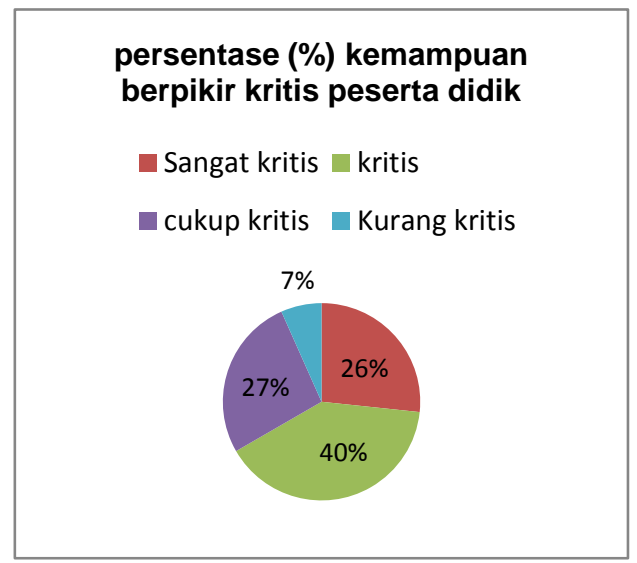

Dari Gambar 4 di atas dapat dijelaskan persentase kemampuan berpikir kritis siswa setelah mengikuti kegiatan pembelajaran pada kompetensi dasar 3.7 menganalisis interaksi antara makhluk hidup dan lingkungannya serta dinamika populasi akibat interaksi tersebut. Hasil penelitian menunjukkkan bahwa kemampuan berpikir kritis peserta didik dari uji coba skala kecil terdiri dari empat kriteria yaitu kriteria sangat kritis (26\%, kriteria kritis (40\%), kriteria cukup kritis (27\%), dan kriteria kurang kritis (7 $\%)$.

Tabel 3 menunjukkan hasil pengukuran kemampuan berpikir kritis peserta didik secara klasikal. Dari tabel dapat dilihat bahwa nilai rata-rata untuk tiap dimensi secara klasikal termasuk dalam kategori kritis. Sama halnya dengan pengukuran kemampuan berpikir kritis dari aspek kinerja, kriteria kemampuan berpikir kritis pada aspek kognitif juga diperoleh dari persentase nilai yang diperoleh. Kriteria kemampuan berpikir termasuk sangat kritis apabila seluruh atau hampir seluruh dari indikator berpikir kritis dapat dipenuhi. Siswa dikatakan termasuk dalam kretria berpikir kritis ini karena sebagian besar indikator berpikir kritis dapat terpenuhi. kriteria berpikir cukup kritis karena hanya sebagian dari indikator berpikir kritis dapat terpenuhi

\section{KESIMPULAN DAN SARAN}

\section{A. Kesimpulan}

1. Jenis nekton yang terdapat di kolam pintar terdapat 7 spesies dan kolam pipi putih terdapat 4 spesies nekton

2. Keanekaragaman jenis nekton yang diperoleh dari kawasan area konservasi Universitas Bengkulu termasuk ke dalam kategori Rendah.

3. Kemampuan berpikir kritis peserta didik dari aspek kinerja termasuk kedalam dua kriteria yaitu sangat kritis dan kritis, sedangkan dari aspek kognitif termasuk kedalam empat kriteria yaitu sangat kritis, kritis, cukup kritis dan kurang kritis

\section{B. Saran}

1. Untuk menjaga keseimbangan ekositem kolam Taman Pintar dan Kolam Kura-Kura Pipi Putih, Maka 
disarankan supaya dilakukan penambahan jenis nekton pada kedua ekosistem Kolam tersebut

2. Perlu dilakukan penelitian lanjutan tentang pengukuran kemampuan berpikir kritis peserta didik dengan menggunakan indikator-indikator berpikir kritis yang lain seperti memfokuskan pertanyaan, menyimpulkan dengan berpikir secara deduksi, mendefenisikan istilah serta dapat di uji cobakan pada materi IPA yang lain dan pada materi IPA yang lain.

\section{Ucapan Terimakasih}

Terima kasih buat pembimbingku Dr.Bhakti Karyadi,M.Pd dan Prof Endang Widi winarni,M.Pd yang selalu memberikan semangat, motivasi dan bimbingan dalam proses penyelesaian jurnal ini.

\section{DAFTAR PUSTAKA}

Amarila,R.S.Habibah,N.A.Widiyatmoko,A. 2014.Pengembangan Alat Evaluasi kemampuan Berpikir Kritis Siswa Pada Pembelajaran Ipa Terpadu Model Webbed Tema Lingku ngan. Unnes Science Education. April 2014.

Journal.http://journal.unnes.ac.id/sju/i ndex.php/usej.

Junaidi, A. Basyuni, M. Muhtadi, A. 2014. Struktur Komunitas Nekton Di Danau Siombak Kecamatan Medan Marelan Kota Medan. Program Studi Manajemen Sumberdaya Perairan, Fakultas Pertanian, Universitas Sumatera Utara. Jurnal Usu volume 7. no 2 Tahun 2016. http://jurnal.usu.ac.id

Karyadi,B.Ruyani,A. Susanta,A. 2016. Pengembangan Model Pembelajaran Di Luar Kelas (Outdoor) Berbasis Lingkungan Alam Bagi Siswa Sd-Sma. Bengkulu:Universitas Bengkulu
Khasnah. 2015. Hakikat kemampuan berpikir kritis.http://digilib.uinsby.ac.id.

Latupapua. 2011. Keanekaragaman Jenis Nekton Di Mangrove Kawasan Segoro Anak Taman Nasional Alas Purwo. Politeknik Perdamaian HalmaheraTobelo. Jurnal Agroforestri Volume VI Nomor 2 Juni 2011. http://jurnalee.files.wordpress.com.

Ningsih, 2016.Aklimatisasi Kura-Kura Pipi Putih (Siebenrokiella crassicollis) Di Area Konservasi Kura-Kura Universitas Bengkulu dan Pengembangan bahan Ajar biologi SMA/MA. [Tesis].Bengkulu. Program Studi Pasca Sarjana Pendidikan IPA. Fakultas Keguruan dan IImu Pendidikan.Universitas Bengkulu

Siagian.2009. Keanekaragaman Dan Kelimpahan Ikan Serta Keterkaitannya Dengan Kualitas Perairan Di Danau Toba Balige Sumatera Utara.Tesis. Sekolah Pascasarjana. Sumatera Utara.

Sinaga, 2016. Studi Adaptasi Kura-Kura Garis Hitam (Cyclemys Oldhamii) Pada Kolam Taman Pintar Fkip Universitas Bengkulu Sebagai Sumber Belajar Konservasi Ex-Situ Bagi Siswa Sma. [Skripsi].Bengkulu. Program Studi Pendidikan Keguruan Biologi.Fakultas Pendidikan.Universitas Bengkulu

Winarni,E,W. 2012. Inovasi Dalam Pembelajaran IPA. Bengkulu: FKIP UNIB. 